\title{
ANALISIS KEMAMPUAN PEMECAHAN MASALAH MATEMATIS SISWA BERDASARKAN MINAT BELAJAR
}

\section{ANALYSIS OF STUDENTS' MATHEMATICAL PROBLEM SOLVING ABILITIES BASED ON LEARNING INTEREST}

\author{
Rizqi Fu'adatul A'yuni ${ }^{a}$, Heni Pujiastuti ${ }^{\mathrm{b}}$ \\ ${ }^{a}$ Program Studi Pendidikan Matematika FKIP Untirta \\ Jl. Raya Jkt Km 4 Jl. Pakupatan, Panancangan, Kec. Cipocok Jaya, Kota Serang, Banten \\ 42124, rizqiayuni@gmail.com \\ ${ }^{\mathrm{b}}$ Program Studi Pendidikan Matematika FKIP Untirta \\ Jl. Raya Jkt Km 4 Jl. Pakupatan, Panancangan, Kec. Cipocok Jaya, Kota Serang, Banten \\ 42124, henipujiastuti@untirta.ac.id
}

\begin{abstract}
ABSTRAK
Tujuan penelitian ini adalah untuk mendeskripsikan kemampuan pemecahan masalah matematis berdasarkan minat belajar. Metode penelitian ini merupakan penelitian deskriptif kualitatif. Subjek penelitian adalah siswa kelas VIIIJ SMPIT Darul Qur'an Bogor. Teknik pengumpulan data dalam penelitian ini berdasarkan angket minat belajar dan tes kemampuan pemecahan masalah matematis. Teknik analisis data yang digunakan dalam penelitian ini adalah pengumpulan data, reduksi data, penyajian data, dan penarikan kesimpulan. Hasil penelitian menunjukkan bahwa, 1) kemampuan pemecahan masalah matematis siswa berdasarkan minat belajar tinggi mempunyai rata-rata sebesar 65,33 yang berada pada kategori baik, 2) kemampuan pemecahan masalah matematis siswa berdasarkan minat belajar sedang mempunyai rata-rata sebesar 60,89 yang berada pada kategori cukup baik, dan 3) kemampuan pemecahan masalah matematis siswa berdasarkan minat belajar rendah mempunyai rata-rata sebesar 50,84 yang berada pada kategori kurang baik.
\end{abstract}

Kata Kunci : Kemampuan Pemecahan Masalah Matematis, Minat Belajar, Deskriptif Kualitatif

\section{ABSTRACT}

The purpose of this research is to describe the ability to solve mathematical problems based on learning interest. This research method is a qualitative descriptive study. The research subjects were students of class VIIIJ Darul Quran Junior High School, Bogor. Data collection techniques in this study were based on a questionnaire of learning interest and tests of mathematical problem solving abilities. Data analysis techniques used in this study were data collection, data reduction, data presentation, and drawing conclusions. The results showed that, 1) students' mathematical problem solving abilities based on high learning interest had an average of 65.33 in the good category, 2) students' mathematical problem solving abilities based on moderate learning interest had an average of 60.89 which is in the good enough category, and 3) students' mathematical problem solving abilities based on low learning interest have an average of 50.84 which is in the unfavorable category.

Keywords: Mathematical Problem Solving Ability, Learning Interest, Qualitative Descriptive 


\section{Pendahuluan}

Matematika merupakan mata pelajaran yang wajib dipelajari pada setiap jenjang pendidikan, mulai dari sekolah dasar hingga ke perguruan tinggi. Matematika sangat berperan penting untuk menunjang keberhasilan dibidang pendidikan. Fungsi mata pelajaran matematika adalah sebagai alat untuk memecahkan masalah baik dalam mata pelajaran lain, dalam dunia kerja, maupun dalam kehidupan sehari-hari (Sapitri et al., 2019).

Terdapat lima standar proses yang harus dimiliki siswa pada pembelajaran matematika, yaitu (1) kemampuan pemecahan masalah, (2) kemampuan penalaran dan pembuktian, (3) kemampuan komunikasi,

kemampuan

mengkoneksikan, dan (5) kemampuan representasi (NCTM, 2000). Salah satu tujuan pelajaran matematika sekolah menengah pertama (SMP) adalah siswa mampu memecahkan masalah yang meliputi kemampuan memahami masalah, merancang model matematika, menyelesaikan model dan menafsirkan solusi yang diperoleh (Permendikbud, 2016). Oleh karena itu, salah satu kemampuan matematis yang harus dimiliki oleh siswa yaitu kemampuan pemecahan masalah. Kemampuan pemecahan tersebut perlu dikuasai agar siswa mampu memecahkan masalah dalam kehidupan sehari-hari. Siswa diharapkan dapat memiliki kemampuan pemecahan masalah dan mengembangkannya untuk menghadapi masalah yang dialami dalam kehidupannya, sehingga kemampuan pemecahan masalah sangat penting untuk dimiliki oleh siswa. Pemecahan masalah bukan hanya sekedar tujuan dari pembelajaran matematika, tetapi juga sebagai keterampilan untuk mengambil keputusan yang terbaik dalam kehidupan (Novitasari \& Wilujeng, 2018).

Kemampuan pemecahan masalah matematis adalah kemampuan yang wajib dimiliki siswa, karena pemecahan masalah memberikan manfaat yang besar kepada siswa dalam melihat relevansi antara matematika dengan mata pelajaran yang lain, serta dalam kehidupan nyata (Sapitri et al., 2019). Dengan pemecahan masalah siswa akan belajar untuk menyusun strategi yang sesuai untuk menyelesaikan permasalahan yang mereka hadapi (Utami \& Wutsqa, 2017). Siswa mampu memecahkan masalah matematika jika mereka mampu memahami, memilih strategi yang tepat, kemudian menerapkannnya dalam penyelesaian masalah. Selain itu pemecahan masalah juga bisa dikatakan langkah awal bagi siswa dalam mengembangkan ide-ide guna membangun 
pengetahuan baru dan mengembangkan keterampilan-keterampilan matematika (Mita et al., 2019).

Meskipun kemampuan pemecahan masalah penting namun kenyataan dilapangan menunjukan bahwa kemampuan ini tergolong rendah. Penelitian dari (Utami \& Wutsqa, 2017) menunjukkan bahwa 389 siswa yang dijadikan subjek penelitian memiiki kemampuan pemecahan masalah yang tergolong dalam kriteria rendah.

Faktor-faktor yang mempengaruhi kemampuan pemecahan masalah dapat berupa aspek kognitif maupun aspek afektif yang meliputi minat, motivasi, kecemasan, dan lainnya (Kudsiyah et al., 2017). Minat belajar merupakan salah satu faktor yang mempengaruhi kemampuan pemecahan masalah. Minat belajar adalah perilaku siswa untuk mewujudkan harapan guru, orang tua, dan teman bahwa dirinya memiliki kemampuan dan kecakapan dalam belajar (Purnama, 2016). Seseorang yang memiliki minat belajar yang positif akan menimbulkan usaha yang gigih, serius, dan tidak mudah putus asa dalam menghadapi setiap permasalahan yang ada (Tambunan, 2016). Jika siswa telah memiliki minat belajar yang positif dalam pembelajaran maka kegiatan pembelajaran akan semakin menyenangkan, serta ia akan berusaha lebih keras dibandingkan siswa yang memiliki minat yang kurang. Jika seseorang kurang berminat dalam pembelajaran matematika maka kemampuan siswa pada bidang matematika akan menjadi terhambat. Sehingga minat belajar berpengaruh terhadap hasil belajar siswa.

Indikator yang peneliti gunakan untuk mengukur kemampuan pemecahan masalah matematis siswa yaitu berdasarkan tahapan model Polya, yaitu: (1) memahami masalah, (2) membuat rencana (3) melaksanakan rencana, (4) memeriksa kembali (Yuwono et al., 2018).

Berdasarkan penjelasan diatas, Peneliti tertarik untuk meneliti dan menganalisis kemampuan pemecahan masalah matematis siswa berdasarkan minat belajar. Tujuan dari penelitian ini adalah untuk menganalisis kemampuan pemecahan masalah matematis siswa berdasarkan minat belajar tinggi, sedang, dan rendah. Penelitian ini mendeskripsikan kemampuan pemecahan masalah matematis siswa berdasarkan minat belajar. Penelitian ini diharapkan akan membantu guru sebagai bahan untuk memilih model pembelajaran yang cocok, serta agar guru dapat membantu siswa yang mengalami permasalahan dalam menyelesaikan masalah. 


\section{Metode Penelitian}

Jenis penelitian ini merupakan penelitian deskriptif dengan menggunakan pendekatan kualitatif. Penelitian ini bertujuan untuk mengetahui bagaimana kemampuan pemecahan masalah matematis bedasarkan minat belajar siswa.

Penelitian ini dilaksanakan di SMPIT Darul Qur'an Bogor. Subjek penelitian adalah siswa kelas VIIIJ SMPIT Darul Qur'an Bogor. Materi yang digunakan yaitu materi bangun datar segi empat.

Prosedur pengumpulan data menggunakan tes dan angket. Tes dilakukan guna mengukur tingkat kemampuan pemecahan masalah matematis siswa. Angket dilakukan guna mengetahui tingkat minat belajar siswa.

Instrumen pada penelitian ini adalah tes dan angket. Tes dengan tiga butir soal dalam bentuk esai yang disusun berdasarkan indikator pemecahan masalah. Tes ini bertujuan untuk mengetahui kemampuan pemecahan masalah matematis pada materi bangun datar segiempat. Angket terdiri dari 25 pertanyaan dengan 12 pernyataan positif dan 13 pernyataan negatif. Angket ini bertujuan untuk melihat bagaimana minat belajar siswa dalam pembelajaran matematika dengan kategori tinggi, sedang, dan rendah. Klasifikasi kriteria tersebut dapat dilihat pada Tabel 1.

Tabel 1. Kriteria Klasifikasi Minat Belajar

\begin{tabular}{cc}
\hline Interval & Kategori \\
\hline Skor $\geq \mathrm{X}$ bar $+\mathrm{S}$ & Tinggi \\
$\mathrm{X}$ bar $-\mathrm{S} \leq$ skor $<\mathrm{X}$ bar $+\mathrm{S}$ & Sedang \\
Skor $<\mathrm{X}$ bar $-\mathrm{S}$ & Rendah \\
\hline
\end{tabular}

(Widyastuti et al., 2018)

Lembar penilaian kemampuan pemecahan masalah matematis mengacu pada empat tahapan pemecahan masalah yaitu sebagai berikut : 
Tabel 2. Lembar Penilaian Kemampuan Pemecahan Masalah Matematis

\begin{tabular}{ccc}
\hline Kriteria & Respon terhadap soal atau/masalah & Skor \\
\hline $\begin{array}{c}\text { Memahami } \\
\text { masalah }\end{array}$ & Ada upaya mengidentifikasi unsur-unsur yang diketahui, ditanyakan, tetapi masih salah & 1 \\
& Dapat mengidentifikasi unsur-unsur yang diketahui, ditanyakan untuk memperoleh & 2 \\
bagian dari penyelesaian tetapi masih kurang lengkap & 3 \\
Merencanakan & Identifikasi unsur lengkap dan benar & 1 \\
penyelesaian & Strategi yang dibuat kurang relevan dan mengarah pada jawaban yang salah & 2 \\
Menyelesaikan & Strategi yang dibuat sudah tepat & 1 \\
masalah & Ada penyelesaian tetapi masih salah & 2 \\
& Penyelesaian masalah ada, tetapi masih terdapat kekeliruan dalam pehitungan & 3 \\
Melakukan & Ada penyelesaian tetapi masih salah Penyelesaian masalah bena & 1 \\
Pengecekan & Kesimpulan yang diberikan salah & 2
\end{tabular}

(Akbar et al., 2017)

Skor yang diperoleh mempresentasikan skor kemampuan pemecahan masalah. Setelah diperoleh skor tes kemampuan pemecahan masalah, peneliti menentukan kategori/kriteria skor yang diperoleh peserta didik. Pemberian kriteria bertujuan untuk mengetahui kategori kemampuan peserta didik dalam memecahkan masalah matematis. Kategori yang digunakan peneliti yaitu sebagai berikut.

Tabel 3. Kategori Interpretasi Skor Kemampuan Pemecahan Masalah Matematis

\begin{tabular}{cc}
\hline Interval & Kategori \\
\hline $80-100$ & Sangat Baik \\
$65-79,99$ & Baik \\
$55-64,99$ & Cukup Baik \\
$40-54,99$ & Kurang Baik \\
$0-39,99$ & Sangat Kurang Baik \\
\hline
\end{tabular}

(Kholifah, 2015)
Teknik analisis data yang digunakan dalam penelitian ini adalah pengumpulan data, reduksi data, penyajian data, dan penarikan kesimpulan (Bustan et al., 2019).

\section{Hasil dan Pembahasan}

Penelitian ini dilaksanakan di SMPIT Darul Qur'an pada salah satu kelas VIII yang berjumlah 25 siswa. Hasil penelitian berupa deskripsi hasil belajar siswa yang menyelesaikan soal kemampuan pemecahan masalah matematis berdasarkan angket minat belajar siswa.

Setelah dilakukan pengukuran minat terhadap matematika pada sampel penelitian, kemudian dilakukan analisis deskriptif berupa penentuan klasifikasi data yang bertujuan untuk mengelompokkan respon pada kategori 
tertentu. Analisis juga dilakukan untuk menentukan statistik deskriptif dari sampel yang ditampilkan pada Tabel 1 berikut.

Tabel 4. Statistik deskriptif minat belajar

\begin{tabular}{cccc}
\multicolumn{4}{c}{ siswa } \\
\hline Skor & Skor & Rata & Simpanga \\
Minimu & Maksimu & -rata & n baku \\
m & $\mathrm{m}$ & & \\
\hline 58 & 90 & 76,24 & 9,7 \\
\hline
\end{tabular}

Berdasarkan Tabel 1 diketahui bahwa sampel memiliki skor minat belajar minimum 58 yang terkategori rendah, skor minat belajar maksimum sebesar 90 yang terkategori tinggi dan memiliki rata-rata minat sebesar 76,24 yang termasuk dalam kategori minat sedang. Adapun hasil dari analisis deskriptif tentang kategori minat belajar siswa ditampilkan pada Tabel 2 berikut.

Tabel 5. Rekapitulasi kategori minat belajar siswa

\begin{tabular}{ccc}
\hline $\begin{array}{c}\text { Kategori } \\
\text { Minat }\end{array}$ & $\begin{array}{c}\text { Banyaknya } \\
\text { Siswa }\end{array}$ & Presentase \\
\hline Tinggi & 5 & $20 \%$ \\
Sedang & 15 & $60 \%$ \\
Rendah & 5 & $20 \%$ \\
Total & 25 & $100 \%$ \\
\hline
\end{tabular}

Berdasarkan Tabel 2 diketahui bahwa secara umum $20 \%$ siswa memiliki minat belajar terhadap matematika dengan kategori tinggi $60 \%$ siswa memiliki minat belajar terhadap matematika dengan kategori sedang, dan $20 \%$ siswa yang memiliki minat belajar terhadap matematika dalam kategori rendah.

\section{Kemampuan Pemecahan Masalah}

\section{Matematis Siswa Berdasarkan Minat Belajar Tinggi}

Berdasarkan hasil pengumpulan data selama penelitian terdapat 5 siswa yang memiliki minat belajar tinggi dengan rata-rata nilai tes kemampuan pemecahan masalah matematis sebesar 65,33. Banyaknya siswa pada tiap-tiap kategori kemampuan pemecahan masalah matematis berdasarkan minat belajar tinggi dapat dilihat pada Gambar 1.

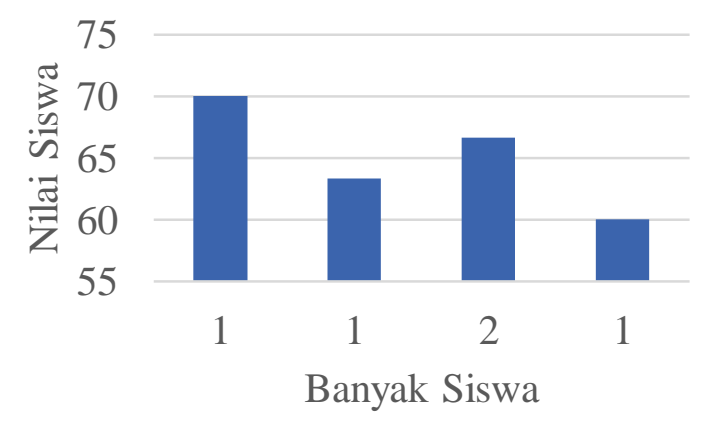

Gambar 1. Kemampuan Pemecahan

Masalah Matematis Siswa Berdasarkan Minat Belajar Tinggi

Dari Gambar 1 terlihat bahwa kemampuan pemecahan masalah matematis siswa paling banyak berada pada kategori baik dan sisanya berada pada kategori cukup. Hal ini berarti bahwa rata-rata kemampuan 
pemecahan masalah matematis siswa berdasarkan minat belajar tinggi kelas VIIIJ SMPIT Darul Qur'an berada pada kategori baik.

Hasil tes kemampuan pemecahan masalah matematis siswa dengan minat belajar tinggi sudah baik. Pada soal pertama, hasil tes menunjukkan bahwa siswa dapat menyelesaikan dengan baik yang mana siswa dapat memahami masalah dengan menuliskan apa yang diketahui dan ditanyakan secara benar, merencanakan penyelesaian sudah tepat, serta dapat melakukan pengecekan dengan benar. Pada soal kedua, hasil tes menunjukan bahwa siswa dapat menyelesaikan dengan baik yang mana siswa dapat memahami masalah dan menuliskan perhitungan secara benar pada satu rumus saja dikarenakan pada tahap merencanakan pemecahan masalah, siswa hanya merencanakan satu cara rumus saja. Pada soal ketiga, hasil tes menunjukan bahwa siswa dapat menyelesaikan dengan cukup baik yang mana siswa sudah tepat dalam membuat strategi penyelesaian hanya saja beberapa siswa tidak menuliskan apa yang diketahui dan ditanyakan.

Hasil di atas menunjukan bahwa siswa dengan minat belajar tinggi mempunyai kemampuan pemecahan masalah yang baik. Hal ini sejalan dengan penelitian (Holidun,
2017) yang menyatakan bahwa siswa yang memiliki minat belajar tinggi dapat melaksanakan semua indikator pemecahan masalah walaupun belum bisa sepenuhnya.

\section{Kemampuan Pemecahan Masalah} Matematis Siswa Berdasarkan Minat Belajar Sedang

Berdasarkan hasil pengumpulan data selama penelitian terdapat 15 siswa yang memiliki minat belajar sedang dengan ratarata nilai tes kemampuan pemecahan masalah matematis sebesar 60,89. Banyaknya siswa pada tiap-tiap kategori kemampuan pemecahan masalah matematis berdasarkan minat belajar sedang dapat dilihat pada Gambar 2.

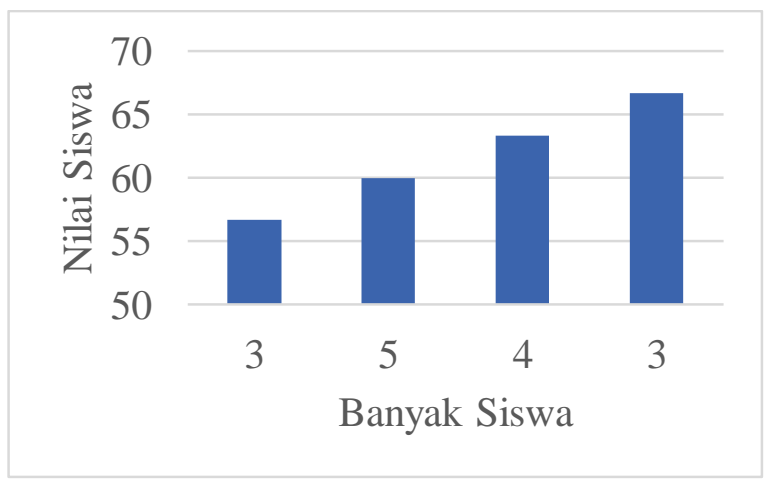

Gambar 2. Kemampuan Pemecahan

Masalah Matematis Siswa Berdasarkan Minat Belajar Sedang

Dari Gambar 2 terlihat bahwa kemampuan pemecahan masalah matematis siswa paling banyak berada pada kategori 
cukup baik dan sisanya berada pada kategori baik. Hal ini berarti bahwa rata-rata kemampuan pemecahan masalah matematis siswa berdasarkan minat belajar tinggi kelas VIIIJ SMPIT Darul Qur'an berada pada kategori cukup baik.

Hasil tes kemampuan pemecahan masalah matematis siswa dengan minat belajar sedang sudah cukup baik. Pada soal pertama, hasil tes menunjukkan bahwa siswa dapat menyelesaikan dengan baik siswa dapat merencanakan penyelesaian dengan tepat, serta dapat melakukan pengecekan dengan benar. Pada soal kedua, hasil tes menunjukan bahwa siswa dapat menyelesaikan dengan cukup baik yang mana siswa dapat menuliskan perhitungan secara benar pada satu rumus saja pada tahap merencanakan pemecahan masalah hanya saja beberapa siswa tidak menuliskan apa yang diketahui dan ditanyakan. Pada soal ketiga, hasil tes menunjukan bahwa siswa dapat menyelesaikan dengan kurang baik yang mana siswa tidak memahami masalah dan belum tepat dalam membuat strategi penyelesaian serta beberapa siswa tidak melakukan pengecekan kembali.

Hasil di atas menunjukan bahwa siswa dengan minat belajar sedang mempunyai kemampuan pemecahan masalah yang sedang. Hal ini sejalan dengan penelitian
(Aftriyati et al., 2019) yang menunjukan bahwa siswa dengan minat belajar sedang dalam menyelesaikan soal pemecahan masalah memenuhi indikator merencanakan penyelesaian, menyelesaikan masalah, dan melakukan pengecekan.

\section{Kemampuan Pemecahan Masalah}

\section{Matematis Siswa Berdasarkan Minat Belajar Rendah}

Berdasarkan hasil pengumpulan data selama penelitian terdapat 5 siswa yang memiliki minat belajar Rendah dengan ratarata nilai tes kemampuan pemecahan masalah matematis sebesar 50,84. Banyaknya siswa pada tiap-tiap kategori kemampuan pemecahan masalah matematis berdasarkan minat belajar rendah dapat dilihat pada Gambar 3.

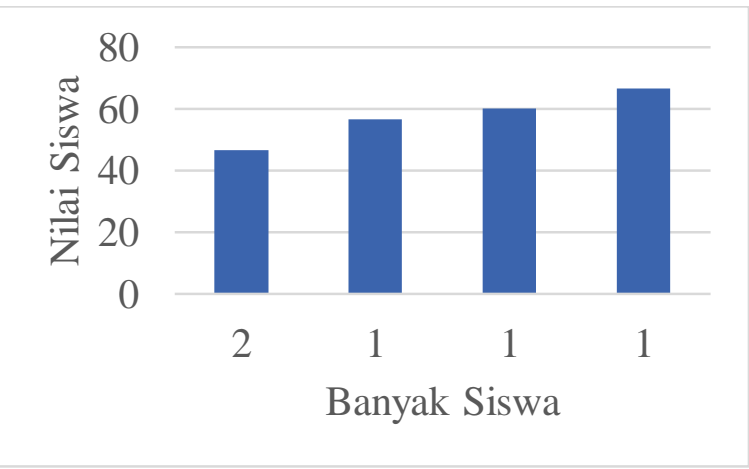

Gambar 3. Kemampuan Pemecahan

Masalah Matematis Siswa Berdasarkan Minat Belajar Rendah 
Dari Gambar 3 terlihat bahwa kemampuan pemecahan masalah matematis siswa paling banyak berada pada kategori kurang baik dan sisanya berada pada kategori cukup baik dan baik. Hal ini berarti bahwa rata-rata kemampuan pemecahan masalah matematis siswa berdasarkan minat belajar rendah kelas VIIIJ SMPIT Darul Qur'an berada pada kategori kurang baik.

Hasil tes kemampuan pemecahan masalah matematis siswa dengan minat belajar rendah kurang baik. Pada soal pertama, hasil tes menunjukkan bahwa siswa dapat menyelesaikan dengan cukup baik yang mana siswa dapat memahami masalah, merencanakan penyelesaian dengan tepat tetapi beberapa siswa tidak melakukan pengecekan dengan benar. Pada soal kedua, hasil tes menunjukan bahwa siswa dapat menyelesaikan dengan baik yang mana siswa menuliskan perhitungan secara benar pada satu rumus saja dikarenakan pada tahap merencanakan pemecahan masalah, siswa hanya merencanakan satu cara rumus saja. Pada soal ketiga, hasil tes menunjukan bahwa siswa menyelesaikan dengan kurang baik yang mana siswa sudah tepat dalam membuat strategi penyelesaian tetapi siswa tidak menuliskan apa yang diketahui dan ditanyakan serta tidak melakukan pengecekan kembali.
Hasil di atas menunjukan bahwa siswa dengan minat belajar rendah mempunyai kemampuan pemecahan masalah yang kurang baik. Hal ini sejalan dengan penelitian (Ninik et al., 2014) yang menunjukan bahwa siswa dengan kategori minat belajar rendah mampu menyelesaikan pada tahapan merencanakan dan menyelesaikan masalah meskipun tahapan lainnya belum maksimal.

\section{Kesimpulan}

Berdasarkan hasil penelitian mengenai analisis kemampuan pemecahan masalah matematis berdasarkan minat belajar siswa dapat disimpulkan bahwa:

1. Kemampuan pemecahan masalah matematis dengan minat belajar tinggi mempunyai rata-rata sebesar 65,33 yang berada pada kategori baik. Siswa mampu memenuhi semua indikator kemampuan pemecahan matematis meliputi: memahami masalah, merencanakan penyelesaian, menyelesaikan masalah, dan melakukan pengecekan.

2. Kemampuan pemecahan masalah matematis siswa dengan minat belajar sedang mempunyai rata-rata sebesar 60,89 yang berada pada kategori cukup baik. Siswa mampu memenuhi indikator merencanakan penyelesaian, 
menyelesaikan masalah, dan melakukan pengecekan.

3. Kemampuan pemecahan masalah matematis siswa dengan minat belajar rendah mempunyai rata-rata sebesar 50,84 yang berada pada kategori kurang baik. Siswa mampu memenuhi indikator merencanakan penyelesaian dan menyelesaikan masalah.

\section{Ucapan Terimakasih}

Peneliti mengucapkan terima kasih kepada Dosen dan Mahasiswa Pendidikan Matematika FKIP Untirta yang telah membantu dalam proses penelitian maupun publikasi dari hasil penelitian ini. Terima kasih juga peneliti sampaikan kepada semua orang yang terlibat dalam penelitian ini.

\section{Pustaka}

Akbar, P., Hamid, A., Bernard, M., \& Sugandi, A. I. (2017). Analisis Kemampuan Pemecahan Masalah Dan Disposisi Matematik Siswa Kelas Xi Sma Putra Juang Dalam Materi Peluang. Jurnal Cendekia: Jurnal Pendidikan Matematika, 2(1), 144-153.

Aftriyati, L. W., \& Roza, Y. (2019). Analisis

Kemampuan Pemecahan Masalah

Berdasarkan Minat Belajar Matematika

Siswa SMA Pekanbaru Pada Materi
SPLTV. Jurnal Matematika, Statistika dan Komputasi, 16(2), 226-240.

Bustan, Ariestha Widyastuty \& Mahmud, Rauman. (2019). Analisis Proses Pembelajaran Matematika pada Anak Berkebutuhan Khusus (ABK) Di Kelas Inklusi SMA Negeri 10 Kota Ternate. adMathEdu, 9(2), 10.

Hafidz, A. A., Kusumaningsih, W., \& Aini, A. N. (2019). Analisis Kemampuan Pemecahan Masalah Matematika Ditinjau dari Motivasi Belajar Siswa Berdasarkan Gender. Imajiner: Jurnal Matematika Dan Pendidikan Matematika, 1(6), 373.

Holidun, H. (2017). Analisis Kemampuan Pemecahan Masalah Matematis Peserta Didik Kelompok Matematika Ilmu Alam (MIA) Dan Ilmu-Ilmu Sosial (IIS) Kelas XI MAN 1 Bandar Lampung Ditinjau Dari Minat Belajar Matematika (Doctoral dissertation, UIN Raden Intan Lampung).

Kemendikbud. (2016). Permendikbud Nomor 22 Tahun 2016 Tentang Standar Proses Pendidikan Dan Menengah. Jakarta: Kemendikbud.

Kholifah, S. (2015). Perbandingan Kemampuan Pemecahan Masalah Matematika Menggunakan Model Pembelajaran Langsung Dengan 
Pembelajaran Berbasis Masalah Kelas VII SMP YPI Darussalam 1 Cerme Gresik (Doctoral dissertation, Universitas Muhammadiyah Gresik).

Kudsiyah, S. M., Novarina, E., \& Lukman, H. suryani. (2017). Faktor-Faktor Yang Mempengaruhi Kemampuan Pemecahan Masalah Matematika Kelas X Di Sma Negeri 2 Kota Sukabumi. Education: Prodi Pendidikan Matematika FKIP Universitas Muhammadiyah Sukabumi, 110-117.

Mita, D. S., Tambunan, L. R., \& Izzati, N. (2019). Analisis Kemampuan Pemecahan Masalah Peserta Didik dalam Menyelesaikan Soal PISA. Lentera Sriwijaya: Jurnal Ilmiah Pendidikan Matematika, 1(2), 25-33.

NCTM. (2000). Principles and Standards for School Mathematics. School Science and Mathematics. Amerika: The National Council of Teachers of Mathematics, Inc.

Ninik, N., Hobri, H., \& Suharto, S. (2014). Analisis Kemampuan Pemecahan Masalah Untuk Setiap Tahap Model Polya Dari Siswasmk Ibu Pakusari Jurusan Multimedia Padapokok Bahasan Program Linier. KadikmA, 5(3).

Novitasari, N., \& Wilujeng, H. (2018). Analisis Kemampuan Pemecahan
Masalah Matematika Siswa SMP Negeri 10 Tangerang. Prima: Jurnal Pendidikan Matematika, 2(2), 137-147.

Purnama, I. M. (2016). Pengaruh Kecerdasan Emosional dan Minat Belajar Terhadap Prestasi Belajar Matematika di SMAN Jakarta Selatan. Formatif: Jurnal Ilmiah Pendidikan MIPA, 6(3), 233-245.

Restina, H. (2018). Kemampuan Pemecahan Masalah Matematis Dan Motivasi Siswa Dengan Model Pembelajaran Creative Problem Solving (CPS). ETD Unsyiah.

Safitri, R. Z. (2019). Profil Kemampuan Pemecahan Masalah Berbentuk OpenEnded Bahasan Pokok Soal Cerita Sistem Persamaan Linear Tiga Variabel Di Kelas X Ma Thohiriyah Ngantru Tulungagung. (Skripsi, Institut Agama Islam Negeri Tulungagung)

Sapitri, Y., Utami, C., \& Mariyam, M. (2019). Analisis Kemampuan Pemecahan Masalah Matematis Siswa dalam Menyelesaikan Soal Open-Ended pada Materi Lingkaran Ditinjau dari Minat Belajar. Variabel, 2(1), 16.

Sumargiyani., Yusnia, Indah., \& Adibah, Yumna. (2019). Analisis Kesalahan Dalam Menyelesaikan Soal Program Linear Berdasarkan Teori Newman. AdMathEdu, 9(2), 10.

Tambunan, N. (2016). Pengaruh Strategi 
Pembelajaran dan Minat Belajar Terhadap Kemampuan Berpikir Kreatif Matematis Siswa. Formatif: Jurnal Ilmiah Pendidikan MIPA, 6(3), 207219.

Utami, R. W., \& Wutsqa, D. U. (2017). Analisis kemampuan pemecahan masalah matematika dan self-efficacy siswa SMP negeri di Kabupaten Ciamis. Jurnal Riset Pendidikan Matematika, $4(2), 166-175$.

Widyastuti, W., Wijaya, A. P., Rumite, W., \& Marpaung, R. R. T. (2018). Minat Siswa Terhadap Matematika Dan Hubungannya Dengan Metode Pembelajaran Dan Efikasi Diri. Jurnal Pendidikan Matematika, 13(1), 83-100. Yuwono, T., Supanggih, M., \& Ferdiani, R. D. (2018). Analisis Kemampuan Pemecahan Masalah Matematika dalam Menyelesaikan Soal Cerita Berdasarkan Prosedur Polya. Jurnal Tadris Matematika, 1(2), 137-144. 